\title{
A Few Sketches on Environments Imprinted on the Novels of Ajneya
}

\section{Beauti Das*}

Assistant Professor, Department of Hindi, Girls' College, Kokrajhar, INDIA

ISSN: 2311-8636 (Print)

ISSN: 2312-2021 (Online)

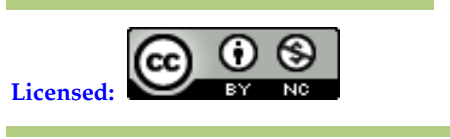

Source of Support: Nil

No Conflict of Interest: Declared

${ }^{*}$ Email for correspondence:

debashishpramanik@gmail.com

\section{ABSTRACT}

It is a well-known fact that the very environment which surrounds us bears a great impact on our body, mind and soul. Anybody can understand what will be the feelings of a person when he is surrounded by cold and heavy air in a situation that he comes in contact. In the same way the feelings of a person in a desert are well understood by anyone without having any question to the person concerned. This is why the environment portrayed by a novelist for the plotline of a novel is so important that it must suit to the characters in question, it must help the smooth progress of the plotline as well as it must pierce in to the heart of a reader, so that the reader can visualize the very movement of the protagonist at every moment of time. To air out our thoughts in this regard it might be the best way to cite the example of the environment that had been created by the great novelist Ernest Hemingway in his novel The Old Man and The Sea. He had allowed the old man to go to the sea again and again for a long period but he never allowed the old man to have success at his hand. In fact he had portrayed an environment of pessimism for the readers by not allowing the old man to have a success at his hand despite of his all efforts. In order to add more pessimism in the mind of a common reader he had given a nick name to the old man by Shalao. The very environment created by the author made every reader believe that the old man will never be successful at any cost, whatever the intensity of his effort may be. This is how one can imagine the influence of the environment on the mindset and belief of a common reader.

Keywords: Neutral Environment, Environment to Establish the Mental Conflict, Environment wherein the Atheist Bows Down in front of Indian Ethical Values, Environment Expressing the Sufferings of the Characters Strife-stricken by Natural Calamities

\section{INTRODUCTION}

In this paper our main aim is to analyze the different techniques that had been employed by the legendary artist Ajneya to create an environment which can motivate the readers to understand the movements of the character concerned. It should be noted that in absence of a proper environment which will not suit to the characters in question, it will not only hamper the mindset of the readers but also resist the smooth progress of the plotline of the 
novel. That is why a successful novelist always endeavours every possible sincere effort to create an environment according to the demand of the situation as it arises. Despite of the very normal environments like political environment, economic environment, social environment, war time environment etc. which are occasionally found as a common place one in a novel according to the demand of the situations; in this paper our efforts will be to pick-up some extra ordinary situations wherein Ajneya handled it very elegantly by creating the best possible suited environment in an artistic way.

\section{Methodology}

Sometimes, though not always literature keeps lingering on a reader's mind and it becomes so intensive when a particular subject matter occupies his or her mind and with the same urge the topic chosen for this write-up also started intruding into our mind so deeply that we began searching for a number of writings, comparative studies written by so many authors including ours who happened to go for research work on the entire novels of Ajneya, who was legendary author in Hindi Literature and the works of contemporary famous Assamese novelist, Dr. Prafulladatta Goswami and in addition to it we took to searching for a good number of books, journals and periodicals etc. in the libraries of various colleges, universities as well as British Library. Besides we had exclusive consultations with the men of authority on the topic chosen for discussion. While drawing conclusions in relation to the topic in question we had a number of views and encouraging suggestions from learned Professors, students and a sizeable number of men of literature having command on the subject matter and having received their views, suggestions etc. we had given due honour to all of them which showed us the correct ladder to move on. This was the methodology that we followed on the track we took to justify the points raised.

\section{FINDINGS}

After thorough discussion and interpretation and reviewing of various comments and write-ups we became very enthusiastic to have come across a few outstanding and exceptional environment-related findings which are detailed below.

Neutral Environment: What really strikes us that in the novel Apne-Apne Ajanabee he has allowed to have a conflict in between Theism and Atheism in such an environment wherein any one of these isms cannot have an extra advantage over the other? For a common man it will be very difficult to think about an environment wherein none of these two can have advantage over the other, what we would like to name as a Neutral Environment. As we know that Atheism has always an extra mileage during day-light. On the other hand Theism always enjoys an extra mileage during darkness of the night. The conflict between Theism and Atheism will never be justified if it will take place either in day-light or in the darkness of the night. The author Ajneya has elegantly created an environment of an ice-laden house wherein Yoke (The representative of atheism) and Selma (The representative of theism) were forced to live under such circumstances wherein both of them could not feel the difference of day-light and darkness of the night. Through such environments Ajneya wanted to bring the triumph card between theism and atheism and he wanted to show which side has the maximum possibility and capability to win over the other. Ajneya can definitely be credited for bringing such a unique conception of two philosophical perceptions with extra-ordinary innovation of two conflicting ideologies pushing each one to win over the other in such a neutral environment. 
Environment to Establish the Mental Conflict: It is common phenomena that the inquisitiveness is always there in the mind of a young child. A young child is always in the hunt to know what is going on surrounding him and because of that he always puts forward so many questions to elder one in order to neutralize inquisitiveness in his mind. However in case of an ordinary child his inquisitiveness can be neutralized only through some answers in either way. Since, Ajneya had an intention to establish his character Shekhar (Shekhar: Ek Jeevani Part-I) as an extraordinary boy, hence he has created such an environment wherein the readers are forced to convince themselves that Shekhar is not really an ordinary boy who cannot be satisfied with naked and shallow answers to the questions he put. For instance, when Shekhar comes to know that many soldiers have to die due to the war that was fought between English and Germans, many questions arose in the mind of the child Shekhar regarding death and in turn he comes to know that only God is responsible for that. As a result he asks lots of questions regarding the very existence of God. The questions put by Shekhar are worth to be quoted in this regard:

Shekhar ne Saraswati se puchhaa marte kaise hain?

Mar jaate hain aur kyaa?

Mar kar kyaa hotaa hain?

Paagal! Jaan naheen rahte, chal phir naheen sakte, tab le jaakar jalaa dete hain (Ajneya, Shekhar Ek Jeevani: Part 1 -Pg. 69).

Shekhar belongs to a middle class family. Like the other kids, Shekhar also comes to know from that environment regarding the matters such as birth, death and price hike etc. and it also comes to Shekhar's childlike mind that all these are made by God. But as the seeker of truth Shekhar gradually loses belief in God because religious superstition brings rigidity during the moulding and shaping of one's personality.

When there was price rise due to the war, people died on account of starvation. Then the only question that arises in Shekhar's mind was that even if the war is over, why the price had escalated; but to satiate his inquisitive mind no right answer was given and God was made responsible for the reason of price rise. Shekhar did not know why the price-rise in the country took place.

Gradually, Shekhar became an atheist. Shekhar could not subscribe to the belief that God, who had always been a hurdle in the pursuit of knowledge, does good for everybody.

When mother would say about the benevolence of the existence of God, then he immediately reacted and quickly responded to it, whatever might happen, because he would ask that whether the war that had recently broken out was also meant for good. Shekhar again asked whether the horse that died, was meant for good. So many people fell ill and died; was it also meant for good, about which he asked his mother. Again he asked his mother whether it could be believed that everything was done by God, but everything good was also done by the same God, that he could not tolerate accepting it.

Once all the family members along with Shekhar went to visit Bhawani Mandir. Shekhar's father was a believer of God. But, Shekhar's atheism was to such an extent that he refused to visit the temple and stated that he did not believe in God.

Main Ishwar ko naheen maantaa, main paarthanaa bhee naheen maantaa, Bhabaani jhuthee hain, Iswar jhutaa hain, Ishwar naheen hain (Ajneya, Shekhar Ek Jeevani: Part 1 -Pg. 77). 
In the similar way Ajneya has created environments wherein child Shekhar never hesitates to express his inner conflicts regarding his concepts on sex, ego, fear, birth etc. Surprisingly, Ajneya has created such an environment that child Shekhar can freely express his sexual feelings with his elder sister Sharaswati. In simple words Ajneya has not left any stone un-thrown to establish that Shekhar is really a boy with extraordinary character. Even in the later part of his life (Shekar: Ek Jiwanee Part-II) Ajneya never forces him to lead his journey with the rites and rituals laid down by the so-called society. As a result of which, Ajneya has created an environment wherein Shekhar can think about (he actually did so also) to lead his life through live- together with one of his cousins by name Sashi. In view of this we must give due weightage to Ajneya for the creation of such nontraditional and extra ordinary environments.

Environment wherein the Atheist Bows Down in front of Indian Ethical Values: In the novel Apne-Apne Ajanabee, Ajneya has created an environment wherein no one is willing to come out of their dwelling houses for the fear of cruel German soldiers. In such an environment everybody becomes unknown to their nearby too. Even they are not interested to know the rest of their surroundings. Peoples are loitering in the street in search of food, a glass of drinking water but none can help them because of acute scarcity of all the essential commodities. In the words of Ajneya the very environment prevails can be expressed as given below:

Bhid bahut thee, lekin pratiyogee bhaaw ke alawaa bhee bhid men sab akele the, bujhe huye bandh sehere maano ghar ki khidkiyaa hee bandh na kar lee gayee ho walki parde bhee khinch diye gaye ho, dabi huyi bhaawnahin par nirmam aawaaje, maano jo maangti ho, use janjir se baandh lenaa chaahti ho, ajanabee sehre, ajanabee aawaaje, ajanabee mudraaye aur woh ajanabeepan kewal ek-dushre ko dur rakh kar ushse bachne kaa hee naheen,walki ek dusre se samparak sthaapit karne kee asamarthataa kaa bhee hain-jaatiyo aur sanskaaro kaa ajanabeepan, jeewan ke mulya kaa ajanabeepan (Ajneya, Apne-Apne Ajanabee: Pg. 82).

One of the main characters Yoke by name somehow makes her free from the captivity of the German soldiers where she was forced to be a sexual worker. To establish the notion of professionalism in her mind, Ajneya allowed her to put on a burning cigar in her leaps and in order to establish desperation she was allowed to consider herself as the Mariam. More than that, she was allowed to snatch the packet of the panneer in the hand of Jagannathan (The representative of Indian ethics and theism) and she tried to flee away from him. In a normal situation Jagannathan should have been angry with her and he should hate her because of her activities. In fact from her past experience in the captivity of the German soldiers, Yoke also expects such retaliation from Jagannathan. On the contrary, coloured with Indian ethical values, Jagannathan follows her not to punish but to know wheather she is in need of his help. Because of the behaviour and the attitude of Jagannathan, Yoke becomes benigned to Jagannathan and immediately she has decided to take her last breath on the lap of Jagannathan. The mental status of Yoke can be well understood by the following dialogue of Yoke:

Kah dungee ki maine chunaa, swechchhaa se chunaa, sab kuchh kah dungee, saaree haraamee duniyaa ko bataa dungee ki ekbaar maine apne man se jo chunaa wohee kyaa, haraamee-haraamee duniyaa, Nathan-achchhe aadmee-mujhe maaf kar do! (Ajneya, Apne-Apne Ajanabee: Pg. 86)

In our view creating such an environment wherein the hardcore atheist Yoke has preferred to take her last ride on the lap of Jagannathan, Ajneya had tried to pictorise a very clear cut 
picture wherein a western hardcore atheist bows down in front of mighty Indian ethical values.

Environment Expressing the Sufferings of the Characters Strife-stricken by Natural Calamities: Environment is the totality of surroundings that one comes in contact with his day to day life; but at the same time natural calamity, an indispensible part and parcel of human life which can neither be avoided nor can be escaped, but we have to face it without any question, for the sake of survival. When someone is under the turbulent and devastating atmosphere of the natural disaster then how the inner instinct, personality and the very behaviour of a person can transform was pictorised by Ajneya in his novel ApneApne Ajanabee through the character Selma. The exceptional behaviour of human being was portrayed so elegantly and minutely under the shadow of natural calamity, even when the death of some nearer took place before the protagonist concerned.

In the episode Selma, Selma talks about the incidents of her struggling life to Yoke. In the town where Selma lived in, the lifestyle of the people was orthodox and backward. There was an old garden, always green with trees and plants, in front of the plain field of the town. Other than a river and a road beside the garden, there was a curved bridge. Beside the bridge Selma, a photographer and Yan had their shops. Selma had a tea shop there. Every year flood fills the river with water, but after a few days everything becomes as before. The devastating flood in the year 1906 resulted in huge piles of destruction. Around that time, the biggest of all accidents were caused by that horrific flood and the incident of the collapse of bridges occured due to the earthquake. In this destructive wave, Selma, Yan and the photographer succeed in surviving the dangerous situation of life and death.

The experience that Selma had in her life through the rough weather she had to face in her course of life made her tough and rough which later on turned her into a much selfish shopkeeper. Due to terrible natural disaster she doubles the price of goods. One day Yan comes to buy wheat and beef but Selma sells them at an excessive price. All the drinking water, the photographer has stored becomes polluted as some broken bottles of medicine fall into the drum of water. So on the second day the photographer comes to Selma, asking her for drinking water, but ruthless Selma refuses to give him any drinking water and she says so:

Paanee mere paas shaayad chaay banaane laayak bhar hogaa, maine abhee chaay bhee naheen banaayee hain, kaho to wohee paanee tumhe de du, yaa ki yaheen ek piyaalaa chaay pee lo (Ajneya, Apne-Apne Ajanabee: Pg. 57).

Selfish Selma, who kept account of profit-loss in business, is an intensely self centric lady. On the 4th day of the aforesaid incident, Yan again buys dry beef and also milk from Selma. Selma notices Yan, who is almost bankrupt and the photographer burns a few toys to prepare tea as they could not afford tea from Selma at an excessive rate. Because of drinking unhygienic water, the photographer's body has already turned yellow and he becomes sick. One night out of desperation, he is forced to kill himself by burning his shop and jumping in the stream of the river. Although, for a moment, the photographer's landlord keeps on staring at the incident of self immolation but they could not save him and his death makes Selma anxious. Out of emotions she states:

Maano Photographer ki woh unmatta mudraa usne fir dekhee, woh paagal cheekh fir sunee, aur fir paanee ki budbudaahat aur fir woh ek swar ghargharaahat, jise ghere huye use na jaane kitne din ho gaye the (Ajneya, Apne-Apne Ajanabee: Pg. 63). 
Yan comes to buy beef from Selma, who always thinks of gathering profit, which is the only motto of her business. As Yan could not give the required sum of money, Selma gives him only the half part of the piece of the beef. There must be a reason behind Selma's such an act; but this attitude of Selma only expresses her immoral as well as inhuman identity. Moreover, though Selma provides her argument that she is innocent of the death of the photographer by which she actually tries to conceal her guilt, which is created in some corner of her mind, she says:

Photographer paagal hokar mar gayaa to main kyaa kar saktee hun? Main bhee paagal naheen ho gayee, isliye kyaa main apraadhee hun (Ajneya, Apne-Apne Ajanabee: Pg. 65)?

Later at night, Yan comes to Selma's house to share with her, the last meal he cooked himself, but being suspicious of his advent at the hour of the night, Selma refuses to open the door. But a little later, to ensure her security, she opens the door with a rod in her hand. Having seen a rod in Selma's hand, Yan comments:

Tumne meree jaan lenee chaahee hain, lekin sakee naheen-saktee naheen.Main chaahun to tumhaaree jaan le saktaa hun-lekin main chaahtaa naheen hun (Ajneya, Apne-Apne Ajanabee: Pg. 66).

Being close to Selma, as they were in the same adjacent small market of day to day transaction for the local people, Yan could understand the feeling of loneliness, unsocial behaviour, self-centric activities of Selma. References may be made of Selma's such way of life as it is already made clear that the bitter experiences that she had to be confronted with in the midst of the rare of the rarest and unwarranted natural calamities and hence her such rude and selfish behaviour. On the basis of such arguments Yan tries to establish Selma as a hard-hearted girl running after money only and he makes the following comments in this regard:

Maregaa to shaayad ham dono men se koi naheen-tumhaaree harkat ke baawjud abhee to naheen lagtaa ki main marnewaalaa hun, lekin agar sachmuch yehaa baarh eyesi hee itne dino tak raheen ki main bhukhaa mar jaau, to tum bachkar kaahaa jaaungee aur agar pichhe hee marogee to tum samajtee ho ki waise akele marne men koi barhaa sukh hai? Walki akelee to tum ab bhee ho jabki main naheen hun aur shaayad mar hee chukee hojabki main abhee jindaa hun (Ajneya, Apne-Apne Ajanabee: Pg. 66).

Arguments after counter arguments between Yan and Selma bring the bridge of differences at the minimal level and Selma starts to understand Yan better with more humanistic attitude. And this can be known from the conversation that occurs in between them:

Tum to maafee maangne aaye the-yah kyaa naye sire se apmaan naheen kar rahe ho (Ajneya, Apne-Apne Ajanabee: Pg. 66)?

Actually, Yan came to Selma with a plan to have the last meal of his life, by cooking the beef that he bought from Selma, with the final fund of his life:

Isliye saajhaa karne aayaa hun, apnee antim punjee dekar yeh antim bhojan maine khareedaa hain, ise akele naheen khaa sakungaa! Aur ise pakaanaa bhee kuchh aasaan naheen thaa-Photographer kee jalee hui dukaan kee aanch par hee yeh pakaa hain, ise jarur hee bahut suwaadu honaa chaahiye-mere jeewan ke mol yah khareedaa gayaa aur Photographer ke jeewan ke mol pak sakaa (Ajneya, Apne-Apne Ajanabee: Pg. 66).

As an artist a novelist can handle an atmosphere or an environment with his meritorious creativity to give a dynamic look to his work of art and in this regard Ajneya as a novelist has 
exceptionally applied his innovative thinking and he has juxtaposed his high sense of creativity with magic like potentialities of bringing new and fresh ideas into the arena of his creations. The environment created by Ajneya in the above mentioned situations is suffice to establish himself as a superb and amazing innovator of amalgamation of exceptional environments inviting the careful attention of the readers of literature to go deep in understanding the plot line of the protagonist as he or she is drawn to the line of struggle of life.

\section{Final Conclusion}

The well-known figure of Hindi literature Ajneya is always to be credited with immense reverence as he created such an awe-inspiring environments which were at par with the world classics though Hindi literature had long way to go to reach its destination in establishing itself to keep pace with the contemporary world literature. It did happen in case of Ajneya only because he gathered unbound store of knowledge by travelling a lot to far and off places in the world. As an author Ajneya earned his fame for his exceptional and extraordinary innovative concepts in applying the opportunities at hand to give shape and colour to the environments that he picked-up for adequate and proper use of as those streams of environments came to his mind as amazing pieces of ideas which can be kept for comparison at par with the best and world renowned novels. Among his much sought-after novels, especially in Apne-Apne Ajanabee the concept of Neutral environment is unique and it establishes the fact that Ajneya had immense potentialities to go to that arena of thoughts even where the world famous authors could not have thrown a ray of light into for which Ajneya could definitely curve a place of his own in the world literature in spite of the fact that open novels just started appearing as a form of art in Hindi literature during the said period. His role as a novelist during the period when he began to write was courageous but on the other hand its effects were tremendous; because the then society was bound by so many social rites and rituals, socalled ethical values and some unwanted superstitious beliefs which restricted the thinking of the upcoming generations by slamming the door behind for letting fresh air of some innovative creations; but in spite of such odds Ajneya could break the ice and inscribed a record as a pioneer of open novels in Hindi literature.

\section{REFERENCES}

Ajneya, Shekhar Ek Jeevani: Part-1 - (In Hindi), Published by Rajkamal Prakashan, 2014, ISBN 10: 8126727365

Ajneya, SHV. Apne Apne Ajnabi, Published by Varanasi: Bharathiya Njanpid Prakashan, 1970. ISBN: 978-81-263-3053-9 
Publish Online and Print Version Both

Online ISSN: 2312-2021

Google Scholar: https://goo.gl/eozEWi 